Revista Eletrônica Geografar, Curitiba, v. 2, Resumos do VI Seminário Interno de Pós-Graduação em Geografia, p. 21-21. Junho/2007

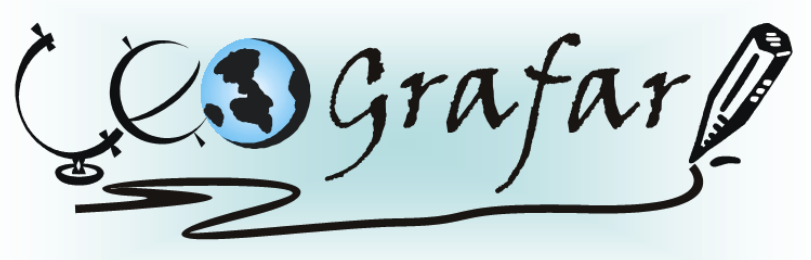

Revista Eletrônica do Programa de Pós-Graduação em Geografia - UFPR

\title{
MAPEAMENTO DA QUALIDADE AMBIENTAL URBANA NO BAIRRO DE SANTA FELICIDADE EM CURITIBA / PR
}

\section{EDGAR SCHMIDT ${ }^{1}$}

Atualmente, o planejamento do uso da terra tem ignorado as questões ambientais, priorizando apenas os fatores econômicos. Com isso, a população urbana acaba se beneficiando com as oportunidades sociais e culturais oferecidas nas cidades, porém convivendo com um ambiente que a cada dia se torna mais deteriorado. Com base nessas colocações, o presente projeto tem por objetivo a aplicação de um método simples de construção de uma carta de qualidade ambiental urbana, baseado no levantamento e representação cartográfica de atributos negativos em escalas que valorizem o cotidiano do cidadão (1:2.000 a 1:10.000). Esse método, fundamentado no "Planejamento da Paisagem", consiste em identificar a partir de visitas a campo e pesquisa documental, variáveis ou atributos negativos que venham a comprometer a qualidade ambiental urbana. São eles: carência de cobertura vegetal ou "desertos florísticos", déficit de espaços livres, risco de enchentes, fontes poluidoras, além de possíveis variáveis que porventura venham a ser descobertas no decorrer da pesquisa (verticalização, densidade demográfica e/ou outros). Após o cruzamento das informações em sínteses parciais e posterior síntese final, os resultados serão comparados com os índices encontrados em publicações científicas. Com base na carta de qualidade ambiental será possivel estabelecer áreas com diferentes níveis de qualidade ambiental, bem como identificar as áreas que proporcionam condições mais saudáveis à população urbana. Estudos como este podem subsidiar o planejamento urbano, diagnosticando os limites e aptidões do meio-físico em relação ao uso e ocupação para assim propor um ordenamento da paisagem. Esse planejamento é atribuição de equipes multidiciplinares, em que o geógrafo se torna indispensável.

Palavras-chave: qualidade ambiental, ambiente urbano, Santa Felicidad

${ }^{1}$ Mestrando em Geografia - UFPR - email: edgar.schmidt@bol.com.br Orientador: JOÃO CARLOS NUCCI 